\title{
Two Realist Idealists Theorizing the Rule of Law
}

\section{Sanne Taekema ${ }^{1}$}

Published online: 5 November 2019

(c) The Author(s) 2019

\begin{abstract}
This contribution discusses the links between Martin Krygier's and Philip Selznick's work on the ideal of the rule of law. The way Krygier explains and reconstructs Selznick's theory is helpful, and yet raises questions about the content and application of the ideal. Understanding the development of the rule of law and the interrelation with another central legal ideal, justice, requires not only a realistic assessment but also a theoretical engagement with the ideals at stake.
\end{abstract}

Life is a web of relationships. My first introduction to Martin Krygier's work was by our common inspiration, Philip Selznick. When I started researching the rule of law more specifically, Krygier's teleological rule of law theory and his ideas about context and tradition became crucial contributions that helped me clarify my own thinking about the rule of law. Although these were different routes, they are held together by the Selznick connection. For quite a few years, talking to him meant asking about his Selznick project, which eventually became the book Philip Selznick: Ideals in the World (1964). Considering these links I realized that, maybe even more than his rule of law work as such, I appreciate Krygier's unwavering loyalty to Selznick's thought and his mission to show its relevance. It therefore seems apt to devote this contribution to an engagement with the rule of law in the context of Selznick's theory. Krygier reconstructs and organizes Selznick's theory of ideals in such a way that it helps grasp the elusive ideal of the rule of law, but hard questions remain, particularly when it comes to the different directions to choose from to get beyond the abstract ideal.

As Krygier shows, Selznick's views of law and the rule of law were part of a broader vision of the importance of values in human life and a concern for the obstacles to their realization. Krygier unpacks the place of values in research by distinguishing four ways in which they play a role in Selznick's work (2012, 204-206). The first is the claim that people have values, that they matter to them. As Krygier points out, this claim is embedded in Selznick's Deweyan philosophy: that people

Sanne Taekema

Taekema@law.eur.nl

1 Rotterdam, The Netherlands 
refer to values in problem-solving (Krygier 2012, 204). The second way in which values figure is as unifying many of our practices into normative systems governed by a master ideal, law being a prime example (Selznick 1961). The third claim is that a researcher can assess the extent to which values are realized in a particular normative system. This claim, for which Krygier coins the term 'clinical assessment', is probably most clearly explained in 'A Normative Theory of Culture' (Jaeger and Selznick 1964). One of Selznick's ongoing concerns was with qualitative states of social practices and in this article he applied the idea to cultures: some cultures can be seen as weak, others as strong. Such an assessment involves appraising the extent to which values are realized in social life. The fourth claim is the most controversial, that values may be used to evaluate morally, based on one's own convictions (Krygier 2012, 205). For Selznick, such evaluations can be objectively warranted. At that point, Selznick can be characterized as a naturalist about values: in certain contexts, specific values are good. As Krygier argues, the first two claims can easily be accepted by any social scientist. The third and fourth claims are controversial, because they involve normative judgments on the part of the researcher. I think that making the distinction between the third claim, assessment based on internal standards of a normative system, and the fourth, moral evaluation tout court, is particularly helpful for lawyers and rule of law scholars. Recognizing the legal standards internal to a normative system as standards of assessment does not necessarily lead to endorsing these values as one's own moral or political convictions. Using the ideal as a standard is important to get beyond a simple reference to what people believe in. It is not particularly clear, however, how to derive the rule of law ideal that is to serve as the standard, nor is it an easy task to justify one's formulation of it.

To make good use of the idea of a clinical assessment of the rule of law, it seems important to have a clear idea, not only of the core ideal, but also of the ways in which it can be (partly) realized or violated. In order to make such a judgment, we need to recognize elements in legal practices as positive or negative in terms of the rule of law. It has always puzzled me why both Krygier and Selznick have resisted formulating more specific rule of law qualities. Their common strategy is to formulate the ideal of the rule of law theoretically, as the ideal we need to accept if we want to understand the central purpose, and to argue that there is immense variation in the realization of that ideal in legal practices, which demands attention to context (Krygier 2011, 69; Krygier 2009; Selznick 2003). Selznick defines the rule of law, or the ideal of legality as "the progressive reduction of arbitrariness in positive law and its administration" $(1969,12)$. Krygier shares the focus on arbitrariness, but specifies the problem as arbitrary exercise of power. Both Krygier and Selznick are interested in extending the reach of the rule of law beyond the state, but with what I see as a slightly different approach. Where Selznick looks for broader developments towards recognition of legality, Krygier is primarily interested in power relationships in various contexts (Selznick 1969; Krygier 2016). Thus, while looking at the same practice, such as powerful private organizations, they approach the problem differently: Selznick identifies legal authority and legal activities of private actors first, Krygier turns more directly to the social problem of how powerful private actors exercise that power $(2016,215)$. It could be mainly a matter of defining the problem, but it may also be due to the ambitions for the theory: Selznick's ambition 
was to develop a sociological jurisprudence, Krygier's to develop a theory of the rule of law (Krygier 2017). A few other differences are significant: Krygier does not claim that the problem is about positive law, but rather that law is the core means to counter arbitrariness. He gives different formulations of what the rule of law may do to arbitrary power. A small sample: it is "legal reduction of the possibility of arbitrary exercise of power by those in a position to wield significant power" (Krygier $2011,75)$, "curbing arbitrariness in the exercise of power" $(2006,133)$, or "tempering the exercise of power" $(2017,302)$. The focus in Krygier's definition shifts from a quantitative reduction to a qualitative change, a better exercise of power. The rule of law is not simply about less exercise of power, which may be dangerous too, but about a use of power in a more acceptable way $(2016,224)$. What is most significant here in comparison to Selznick is that Krygier does not speak about 'progressive' reduction. On the contrary, we can have too much of a good thing; seeking to realize non-arbitrariness endlessly may lead us to claim too much for the rule of law. It is just one value, after all. Whereas Selznick and Krygier are both realists about the ideal of the rule of law, I would say that Selznick is the one who has higher hopes.

In my view, this is the point where rule of law thinking in the Selznick/Krygier vein comes to a fork in the road. Either we follow Krygier's path and say that rule of law is just one value, but that there are others that are equally important for law, or we follow Selznick's and pack the rule of law with richer notions of non-arbitrariness. I see the choice as one between different forms of theorizing the pluralism of ideals: is the rule of law one ideal among a number of legal ideals, or is it an overarching ideal with more constitutive values? Another way to see it is as the question where to locate variation: is it only the practice that varies or is it also the ideal itself? The easiest illustration of the point is the way the rule of law figures in Selznick's best-known book, Law and Society in Transition (Nonet and Selznick 1978). Nonet and Selznick show how an internal dynamic pushes law from a stage of repressive law, in which law is a crude instrument of politics, to autonomous law, in which law's integrity and formality are central, to a third stage of responsive law, in which law serves a substantive purpose and is linked to policy. One of the distinguishing traits of the three types of law is their relationship to the rule of law. Repressive law, serving political power, does not include a rule of law orientation. In autonomous law, by contrast, the rule of law is the central concern. Krygier criticizes Law and Society in Transition for the "identification of the rule of law with a particular configuration of institutions rather than a large and variously implementable, 'practical ideal'..." $(2012,175) .{ }^{1}$ As Krygier shows, identifying the rule of law with the institutions of formal law is inconsistent with Selznick's other work, which is open to expanding the rule of law to other practices and institutions. ${ }^{2}$ Krygier argues that the strength of seeing the rule of law as a practical ideal is lost if it is tied to specific institutional settings or mechanisms. An ideal can be variably realized and needs to be realized in different ways in different contexts. If we see the rule of law as an ideal, it can also be connected to other types of law. One of the important

\footnotetext{
1 The reference to the rule of law as a practical ideal comes from Selznick (1999, p 21).

2 Most importantly, Selznick (1969), which extends the reach of the rule of law to private power.
} 
points made by Krygier is that autonomous law and responsive law should not be regarded as separate stages: responsive law builds on a framework of autonomous law (192). Once the baseline of autonomous law is in place, there are opportunities for introducing responsive law. For him, Selznick's arguments entail that we need to pay attention to the strength of the legal order; where the legal institutions are strong already, departing from formal rules and focusing on policy and purpose is safe, where legal institutions and the legal profession are weak, this is a dangerous strategy (193-194). Krygier is right in concluding that “... responsive law is to be built on an autonomous legal order; it is not intended to undermine it" (192).

However, I think this has important implications for the rule of law as a theoretical construct. On the basis of the connection between autonomous and responsive law, we can also see continuities in the rule of law ideal connected to each type. Most importantly, the idea of legality as the progressive reduction of arbitrariness does not disappear in responsive law, it takes a different form: "To press for a maximum feasible reduction of arbitrariness is to demand a system of law that is capable of reaching beyond formal regularity and procedural fairness to substantive justice." (Nonet and Selznick 1978, 108). Using the same definition of legality as in the earlier work, Nonet and Selznick stress that legality remains the master ideal of law. To my mind, Krygier's critique that they identify the rule of law with autonomous law is not really deserved. It is true that the rule of law is sometimes described as an institutional system rather than as an ideal (Nonet and Selznick 1978, 53), but the ideal of legality is still central. And since legality in the earlier work was taken to be identical to the ideal of the rule of law, the substance of the rule of law ideal is present in responsive law too. The meaning of the rule of law ideal does change considerably: in autonomous law, it demands negative restrictions on authority; in responsive law, it demands the achievement of justice. I see this interpretation confirmed in Selznick's discussion of law in The Moral Commonwealth; reading it differently than Krygier, who sees it as a correction of the earlier view $(2012,266)$. Here, the same notion of 'progressive reduction of arbitrariness' is now put forward as the aim of 'a science of justice' (Selznick 1992, 445). As Krygier also notes, Selznick subscribes to the view that autonomous law and rule of law provide a baseline on which a more responsive legal order may be built. Does this mean that rule of law and justice are separate ideals? I think that would not be in line with Selznick's integrative vision. If rule of law provides a baseline of limited arbitrariness in a legal order, that legal order only flourishes if it reaches beyond that to a vision of justice. The broad ideal of justice encompasses the more modest ideal of rule of law.

Where Selznick's view changes by enlarging the aspirations invoked by the progressive reduction of arbitrariness, Krygier's claims seem to become more modest. As rule of law scholars we might overplay our hand if we start to claim that rule of law is the way to build a just world. I believe it makes sense to distinguish the ideal of the rule of law from the ideal of justice. This does not mean, however, that the ideal of the rule of law can be kept separate from that ideal. Quite a while ago, I argued that both rule of law, or legality, and justice need to be seen as governing ideals of the practice of law and that their relative importance may vary (Taekema 2003, 188). The focus of a particular legal system may shift from giving more weight to providing legal certainty - a central aspect of rule of law- to more realization of 
real equality - a core notion of justice. For instance, the current discussions about the failure of the South-African constitution to alleviate structural inequalities can be read as a shift in emphasis from rule of law to justice. To be honest, I am not quite sure what Krygier thinks about this: is justice a legal ideal of similar import as the rule of law? When thinking about the rule of law, I find it difficult to keep these ideals separate; pragmatically, I see them as being distinguishable but interconnected. This means that I am happy with the idea of a rule of law ideal as limited to restraining arbitrary exercise of power, but that in practice this will touch upon different aspects of justice as well. As most rule of law scholars would agree, it is not meaningful to speak of non-arbitrariness without considering the fairness of procedure or the equal application of legal rules, both aspects that I see as expressing an ideal of justice. It is when the ideal of the rule of law needs to be applied to specific contexts that such conceptual distinctions become particularly difficult to uphold.

Moreover, an assessment of the rule of law as practiced in a particular context cannot escape specifying the meaning of the ideal. Although I agree with Krygier in the abstract that we cannot identify the rule of law ideal with particular institutional arrangements, in the current context of, for example, Hungary, Poland and Romania, it is the institutional principle of the independence of the judiciary that is used to judge whether the rule of law is under threat. But how should we view the relationship between non-arbitrariness and the separation of powers? Judicial independence is regarded as a necessary component of the rule of law without a specific argument as to why it is so crucial. It seems that we fall back on the 'laundry lists' of rule of law requirements after all.

Specifying the ideal for application also makes the problem of the different constitutive values of the rule of law acute. The variability of the problems of arbitrary power is mirrored by a variety of value dimensions of the rule of law. Krygier unpacks the problem and distinguishes three different senses of arbitrariness: whimsical power, unruliness, a lack of recognition of the interests of subjects (Krygier 2016, 204). I associate these problems with the positive values we pursue to avoid them: with reasoned justification, with predictability, and with participation, while I would think that the fairness of decisions is also a crucial component (Mak and Taekema 2016). These values may sometimes reinforce each other and at other times conflict (Waldron 2011). This makes it hard to use them for assessment: when to prioritize one over the other and why to do so are hard determinations to make. I used to think that a problem-solving orientation would help-paying sufficient attention to the specific context and experienced problems. I am less confident now: there are many situations in which people have different experiences and different interpretations of what matters, also when it comes to the rule of law. Such pluralism not only calls for equal voice and participation but may also demand respect for, and predictable application of, the few principles that people do agree upon. This may mean that conserving institutions and principles that have protected the rule of law well enough in the past may be the best we can do. Although this is a less optimistic conclusion than I would like, this may be what realism about the rule of law ideal implies. 
Open Access This article is distributed under the terms of the Creative Commons Attribution 4.0 International License (http://creativecommons.org/licenses/by/4.0/), which permits unrestricted use, distribution, and reproduction in any medium, provided you give appropriate credit to the original author(s) and the source, provide a link to the Creative Commons license, and indicate if changes were made.

\section{References}

Jaeger G, Selznick P (1964) A normative theory of culture. Am Sociol Rev 29:653-669

Krygier M (2006) The rule of law: an abuser's guide. In: Sajo A (ed) Abuse: the dark side of human rights. Eleven, The Hague, pp 129-161

Krygier M (2009) The rule of law: legality, teleology, sociology. In: Palombella G, Walker N (eds) Relocating the rule of law. Hart, Oxford, pp 45-70

Krygier M (2011) Four puzzles about the rule of law: why, what, where? And who cares? In: Fleming J (ed) Getting to the rule of law. New York University Press, New York, pp 64-104

Krygier M (2012) Philip Selznick: ideals in the world. Stanford University Press, Stanford

Krygier M (2016) The rule of law: pasts, presents and two possible futures. Ann Rev Law Soc Sci 12:199-229

Krygier M (2017) Legal pluralism and the value of the rule of law. In: Roughan N, Halpin A (eds) In pursuit of pluralist jurisprudence. Cambridge University Press, Cambridge, pp 294-325

Mak E, Taekema S (2016) The European Union's rule of law agenda: identifying its core and contextualizing its application. Hague J Rule Law. https://doi.org/10.1007/s40803-016-0022-1

Nonet P, Selznick P (1978) Law and society in transition: towards responsive law. Harper \& Row, New York

Selznick P (1961) Sociology and natural law. Nat Law Forum 6:84-108

Selznick P (with P Nonet and H Vollmer) (1969) Law, society and industrial justice. Russell Sage Foundation, New York

Selznick P (1992) The moral commonwealth: social theory and the promise of community. University of California Press, Berkeley

Selznick P (1999) Legal cultures and the rule of law. In: Krygier M, Czarnota A (eds) The rule of law after communism. Ashgate, Dartmouth, pp 21-38

Selznick P (2003) 'Law in context' revisited. J Law Soc 30:177-186

Taekema S (2003) The concept of ideals in legal theory. Kluwer Law International, The Hague

Waldron J (2011) The rule of law and the importance of procedure. In: Fleming J (ed) Getting to the Rule of Law. New York University Press, New York/London, pp 3-31

Publisher's Note Springer Nature remains neutral with regard to jurisdictional claims in published maps and institutional affiliations. 